\title{
Improving sustainable hydrogen production from green waste: [FeFe]-hydrogenases quantitative gene expression RT-qPCR analysis in presence of autochthonous consortia
}

\author{
M. Arizzi ${ }^{1,5}$, S. Morra ${ }^{1,4}$, G. Gilardi ${ }^{1}$, M. Pugliese ${ }^{2,3}$, M. L. Gullino 2,3 and F. Valetti ${ }^{1 *}$
}

\begin{abstract}
Background: Bio-hydrogen production via dark fermentation of low-value waste is a potent and simple mean of recovering energy, maximising the harvesting of reducing equivalents to produce the cleanest fuel amongst renewables. Following several position papers from companies and public bodies, the hydrogen economy is regaining interest, especially in combination with circular economy and the environmental benefits of short local supply chains, aiming at zero net emission of greenhouse gases (GHG). The biomasses attracting the largest interest are agricultural and urban green wastes (pruning of trees, collected leaves, grass clippings from public parks and boulevards), which are usually employed in compost production, with some concerns over the GHG emission during the process. Here, an alternative application of green wastes, low-value compost and intermediate products (partially composted but unsuitable for completing the process) is studied, pointing at the autochthonous microbial consortium as an already selected source of implementation for biomass degradation and hydrogen production. The biocatalysts investigated as mainly relevant for hydrogen production were the [FeFe]-hydrogenases expressed in Clostridia, given their very high turnover rates.
\end{abstract}

Results: Bio-hydrogen accumulation was related to the modulation of gene expression of multiple [FeFe]-hydrogenases from two strains (Clostridium beijerinckii AM2 and Clostridium tyrobutyricum AM6) isolated from the same waste. Reverse Transcriptase quantitative PCR (RT-qPCR) was applied over a period of $288 \mathrm{~h}$ and the RT-qPCR results showed that C. beijerinckii AM2 prevailed over C. tyrobutyricum AM6 and a high expression modulation of the 6 different [FeFe]hydrogenase genes of C. beijerinckii in the first $23 \mathrm{~h}$ was observed, sustaining cumulative hydrogen production of 0.6 to $1.2 \mathrm{ml} \mathrm{H}_{2} / \mathrm{g}$ VS (volatile solids). These results are promising in terms of hydrogen yields, given that no pre-treatment was applied, and suggested a complex cellular regulation, linking the performance of dark fermentation with key functional genes involved in bio- $\mathrm{H}_{2}$ production in presence of the autochthonous consortium, with different roles, time, and mode of expression of the involved hydrogenases.

Conclusions: An applicative outcome of the hydrogenases genes quantitative expression analysis can be foreseen in optimising (on the basis of the acquired functional data) hydrogen production from a nutrient-poor green waste and/ or low added value compost, in a perspective of circular bioeconomy.

*Correspondence: francesca.valetti@unito.it

1 Department of Life Sciences and Systems Biology, University of Torino,

Via Accademia Albertina 13, 10123 Torino, Italy

Full list of author information is available at the end of the article original author(s) and the source, provide a link to the Creative Commons licence, and indicate if changes were made. The images or other third party material in this article are included in the article's Creative Commons licence, unless indicated otherwise in a credit line to the material. If material is not included in the article's Creative Commons licence and your intended use is not permitted by statutory regulation or exceeds the permitted use, you will need to obtain permission directly from the copyright holder. To view a copy of this licence, visit http://creativecommons.org/licenses/by/4.0/. The Creative Commons Public Domain Dedication waiver (http://creativeco mmons.org/publicdomain/zero/1.0/) applies to the data made available in this article, unless otherwise stated in a credit line to the data. 
Keywords: [FeFe]-hydrogenase, Reverse transcriptase quantitative PCR (RT-qPCR), Dark fermentative hydrogenproducing bacteria (dHPB), Bio-hydrogen, Clostridium

\section{Background}

The exploitation of wastes to recover new materials, energy and fuels is a key point of circular economy. The biochemical processes are among the most effective strategies to efficiently maximise this approach, and thus the strong and intertwined link between circular economy and bioeconomy. The greenhouse gases (GHG) neutrality is a natural consequence of the equilibrium among the biochemical processes involved in bioeconomy. In the perspective of a constantly growing energy demand, maximising the efficiency of energy recovery from waste and limiting GHG at the same time is an obligate pathway to make the process sustainable and economically feasible. In a biological approach the focus is on recovering the reducing equivalents from organic compounds, avoiding $\mathrm{C}$ and $\mathrm{N}$ loss under the form of GHG. Also, the efforts should focus to the production of bio-fuels which does not produce GHG (or are GHG neutral). In this perspective, bio-hydrogen is a very promising bio-fuel and a detailed research in biochemistry and biotechnology is the tool to reach the envisaged optimisation of the recovering processes.

Hydrogen can be produced by either biological, electrochemical or thermochemical processes. Compared with other biological hydrogen production processes, dark fermentation appears to be the most appealing method for the following reasons: (i) it can continually produce $\mathrm{H}_{2}$ even in the absence of light; (ii) it can use a variety of low-value waste as raw materials such as organic wastewater and waste biomass [1, 2]; (iii) fermentation byproducts with alternative value include butyric, lactic and acetic acid; and (iv) the bacteria used are anaerobic, thus costly sparging with $\mathrm{O}_{2}$ would be spared.

To date, research has been focused on reactor optimisation and fermentation conditions [3-7] while the microbial community structure and how this impacts on $\mathrm{H}_{2}$ production are still topics to be elucidated in more detail, although interest on these aspects is recently growing [7-10].

Dark fermentative hydrogen-producing bacteria (dHPB) such as Clostridium, Ethanoligenens, Enterobacter and Bacillus have been isolated from bioreactors and natural environments and previous studies have shown that culture conditions or operating parameters can significantly affect cell growth and hydrogen production [11]. The identification and characterisation of highly efficient hydrogen-producing bacteria is a very crucial point in applicative term. In order to efficiently operate biohydrogen-producing dark fermentation processes, or adjust parameters upon malfunctions, it is important to understand how the system works in real mixed consortia and in applicative condition. In a hydrogen-fermenting bioreactor, where the community structure, including microorganisms other than hydrogen producers, can change substantially over time [12] functional detection would provide a tool for bioprocess monitoring. Quantification of the main producers, monitoring the expression of their key genes for hydrogen production and monitoring the community structure during operation is essential in order to understand what kind of community changes are linked to changes in the bioreactor operation [13].

Hydrogenases are enzymes known to be responsible for $\mathrm{H}_{2}$ production. They can be divided into three groups based on their metal content in the $\mathrm{H}_{2}$-activating sites: [Fe]-hydrogenases, [FeFe]-hydrogenases, and [NiFe]-hydrogenases.

The [FeFe]-hydrogenases are very efficient hydrogenproducing biocatalysts with a turnover frequency of up to $10^{4} \mathrm{~s}^{-1}$ [14]. They are widespread among bacteria and highly represented in Gram-positive Clostridium spp. [13]. These bacteria are often considered to be the main group of $\mathrm{H}_{2}$ producers in mesophilic, hydrogen-fermenting bioreactors, which makes the [FeFe]-hydrogenase a valuable target for analysis.

[FeFe]-hydrogenases are monomeric, dimeric, trimeric or tetrameric enzymes with a highly modular structure; they have at least a catalytic active $\mathrm{H}$-domain and may present other accessory domains, which are responsible for the large biodiversity in this class of enzymes [14, 15].

In addition, several microorganisms possess more than one [FeFe]-hydrogenase annotated gene-encoding enzymes belonging to different subgroups. This redundancy has only partially been explored [16] and, while it is expected to imply various roles in the cell growth and energetics for the different genes, depending on the time of expression and modulation, the correlation is still elusive.

So far, only few members of the [FeFe]-hydrogenase class have been studied and characterised in details: these enzymes belong to species of the genus Desulfovibrio, especially $D$. desulfuricans (DdH) [17]; species of the genus Clostridium especially C. pasteurianum, with the two variants $\mathrm{CpI}[18]$ and $\mathrm{CpII}[16]$ and $C$. acetobutylicum (CaHydA) [19] as well as some green algae like Chlamydomonas reinhardtii (CrHydA1) [20]. 
It is indeed becoming clearer that the study of new uncharacterised [ $\mathrm{FeFe}]$-hydrogenases might contribute to a broader knowledge of molecular mechanism of $\mathrm{H}_{2}$ production and to the isolation of novel and improved biocatalysts with unexpected features, such as resistance to oxygen damage and quick recovery of full activity upon changes of redox state, gas-sensing-role, high electronexchange efficiency for biotechnological exploitation in bio-hybrid systems (i.e. microbial fuel cells and enzymemodified electrodes) [21-32].

This research had multiple aims: firstly, it aimed at the isolation, identification and characterisation of efficient hydrogen-producing bacteria (with their [FeFe]-hydrogenases as enzyme catalysts) that may be suitable candidates as inoculum on waste biomasses for hydrogen production. In this perspective, the waste matrix and autochthonous consortium used has already demonstrated to be able to sustain hydrogen and methane production [33], but here a detailed description is provided. Secondly, by performing the extensive investigation of the time and mode of genes expression of the newly identified [FeFe]-hydrogenases in a mixed culture naturally present in waste biomass, the work presented here grants data for a better knowledge of the mechanisms of bio-hydrogen production in real dark fermentation systems and an additional information on the fundamental biochemical keys to tune and improve the performances. As a third and more applicative aspect, this work can also contribute to consolidate the use of green waste as a substrate for bio-hydrogen and bio-methane production (and only the resulting digestate for compost production), rather than address the largely available green waste to direct composting, which might result in net loss of recoverable energy and in the typical emission, during composting, of GHG such as methane and $\mathrm{N}_{2} \mathrm{O}$ [34].

\section{Results and discussion}

Isolation and microbial community analysis of hydrogen-producing bacteria from green waste biomass The cultivable microbiota was analysed in an autumnal green waste biomass (named Mix) that is usually sent to standard composting processes. Given the previous evidence that this kind of biomass alone can sustain dark fermentation, producing hydrogen at appreciable levels [33], the interest was to grant a detailed characterisation of the microbiological and biochemical aspects in order to complete the analysis.

All the isolated microorganisms were able to grow in anaerobic conditions and among these 36\% were oxygen-tolerant. The Gram staining showed that all the isolated were Gram +; $26 \%$ of the isolated microorganisms were cocci (all of these were oxygen tolerant) and $74 \%$ bacilli (among these 56\% oxygen-tolerant and 46\% oxygen-sensitive).

Subsequently, the isolates were classified in further detail on a molecular basis, by means of $16 \mathrm{~S}$ rRNAencoding genes restriction fragment length polymorphism (RFLP) analysis. The 16S rRNA-encoding gene was amplified by PCR from each isolated strain and digested with four restriction endonucleases (HaeIII, AluI, HhaI, TaqI).

The morphological features, growth ability and RFLP analysis allowed the subdivision of all the isolated strains into 11 different group types from A to $\mathrm{K}$ (Fig. 1). The identified species (on the basis of the sequencing of $16 \mathrm{~S}$ rRNA-encoding genes with the related uncertainties) are Clostridium beijerinckii, Clostridium tyrobutyricum, Pediococcus acidilactici, Bacillus ginsengihumi, Bacillus licheniformis, Staphylococcus simulans, Lactobacillus mucosae, Lactobacillus fermentum, Lactobacillus acidipiscis, Lactobacillus collonoides and Lactobacillus $s p$.

The identified bacteria, Clostridium sp., Lactobacillus sp., Pediococcus sp., Staphylococcus sp. and Bacillus $s p$. are commonly found in soil or fermentable materials [35-37].

The microbial diversity found in green waste biomass is illustrated through a phylogenetic analysis of $16 \mathrm{~S}$ rRNAencoding genes sequences (Fig. 2).

The consortium was composed of two macro-groups: pro-biotic non-hydrogen-producing bacteria (belonging to the genera Lactobacillus and Bacillus) and hydrogenproducing bacteria (belonging to the genus Clostridium). Recent interest has been given to the interplay of hydrogen producers and non-hydrogen producers in mixed consortia degrading agricultural wastes such as wheat and reed straw [38, 39], and other available wastes such as sugar bagasse [9], highlighting the importance of native waste-associated consortia in regulating the hydrogen production, even outperforming selected inoculum taken from anaerobic digestion plants. The presence of

(See figure on next page.)

Fig. 1 Morphologic and molecular characterisation of 11 different group type of bacteria isolated from green waste biomass. A-K Gram staining of the species. The bacteria shown are: Lactobacillus mucosae (A), Clostridium beijerinckii (B), Pediococcus acidilactici (C), Clostridium tyrobutyricum (D), Lactobacillus fermentum (E), Lactobacillus acidipiscis (F), Lactobacillus collonoides (G), Lactobacillus sp. (H), Bacillus ginsengihumi (I), Staphylococcus simulans (J), Bacillus licheniformis (K). L-O 16S rRNA-encoding genes RFLP analysis of the $\mathbf{A}$ to $\mathbf{K}$ isolated bacteria, using different restriction

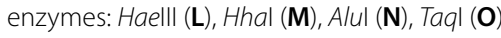




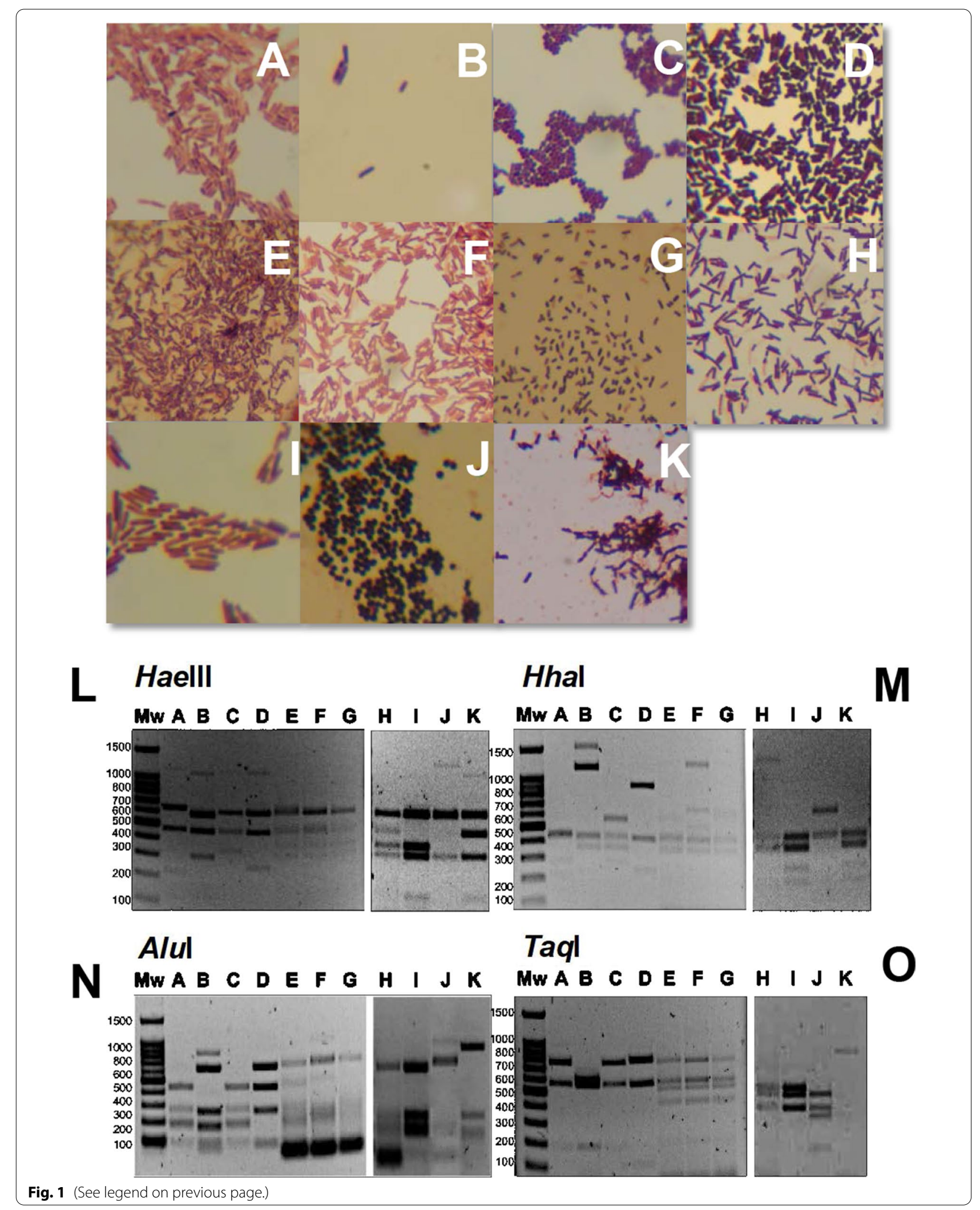




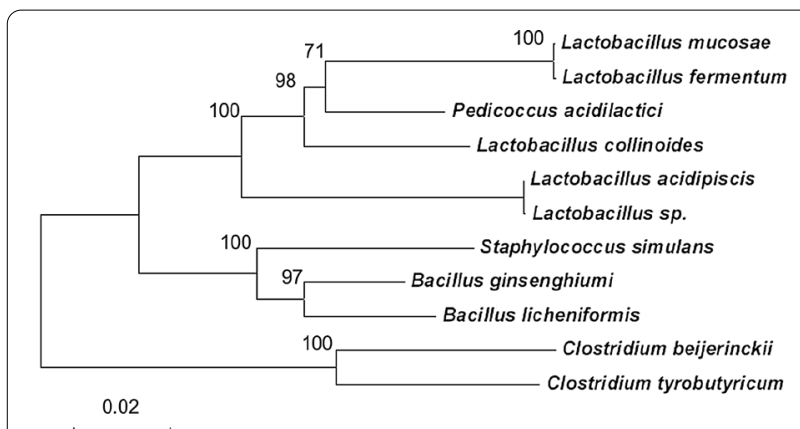

Fig. 2 Phylogenetic tree based on 165 rRNA-encoding gene sequences of the isolate bacteria from green waste. The tree was constructed using the neighbour-joining algorithm. Numbers on the tree refer to bootstrap values on 1000 replicates. The bar indicates a $2 \%$ estimated difference in nucleotide sequences. Analogous phylogenetic analysis of Clostridium beijerinckii compared to other standard Clostridia and of Bacillus ginsengihumi related to reference strains can be found in [37] for Bacilli and in [2] for Clostridia. The reference numbers for the 165 rRNA-encoding gene sequences are listed below (group A to K as specified in Fig. 1 caption): group A: MZ054377, group B: MZ054378, group C: MZ054379, group D: MZ054380, group E: MZ054381, group F: MZ054382, group G: MZ054383, group H: MZ054384, group I: MZ054385, group K: MZ054386

autochthonous Lactobacillus and Bacillus strains in the Mix sample is in line with previously reported analysis of mixed consortia [38-40] and their effect in hydrogen-producing digester. The autochthonous consortium was challenged here with a bio-augmentation strategy, exploiting the good performances already proved by the autochthonous microbiota on similar and very poor substrates in previous analysis [33] and testing a possible positive synergy between the consortium and the added inoculum.

The ability to produce $\mathrm{H}_{2}$ was assayed to investigate the direct involvement in $\mathrm{H}_{2}$ production of each species. As expected, only two species of the genus Clostridium were able to produce $\mathrm{H}_{2}$ : Clostridium beijerinckii and Clostridium tyrobutyricum. Various strains of $C$. beijerinckii were isolated from several sources $[2,29,35,41]$ and $C$. tyrobutyricum has mainly been used in fermentation to produce butyric acid and only limitedly in hydrogen production [42, 43].

However, the hydrogen-producing bacteria isolated here are different strains from those annotated in databases. The $16 \mathrm{~S}$ rRNA-encoding gene sequence of $C$. beijerinckii displayed a $100 \%$ of identity with the $16 \mathrm{~S}$ rRNA-encoding gene of the C. beijerinckii stains annotated in databases, but a further analysis of the sequences of the six annotated hydrogenases for this species showed few differences, hence the name $C$. beijerinckii AM2. The $16 \mathrm{~S}$ rRNA-encoding gene of $C$. tyrobutyricum showed a
99\% of identity with two of the C. tyrobutyricum stains annotated in databases, therefore named C. tyrobutyricum AM6. The two novel strains isolated were found to be two efficient hydrogen producers: $C$. beijerinckii AM2 produced $299.4 \pm 2 \mathrm{~mL}$ of $\mathrm{H}_{2}$ per $\mathrm{g}$ of glucose and $C$. tyrobutyricum AM6 released $246 \pm 7 \mathrm{~mL}$ of $\mathrm{H}_{2}$ per g of glucose when tested as individual isolates.

The maximum hydrogen yields of the strain isolated from green waste were higher than those previously reported in the literature for other hydrogen-producing bacteria like C. perfringens $130 \pm 3 \mathrm{~mL}$ of $\mathrm{H}_{2}$ per g of glucose [35]; C. butyricum $136 \pm 5 \mathrm{~mL}$ of $\mathrm{H}_{2}$ per g of glucose [35]; C. diolis $150 \mathrm{~mL}$ of $\mathrm{H}_{2}$ per g of glucose [44]; C. beijerinckii Fanp3 $231 \mathrm{~mL}$ of $\mathrm{H}_{2}$ per g of glucose [29] and $C$. tyrobutyricum JM1 $223 \mathrm{ml}$ of $\mathrm{H}_{2}$ per g of hexose [42].

Therefore, these novel strains (C. beijerinckii AM2 and C. tyrobutyricum AM6) were selected for the identification of their [FeFe]-hydrogenases and quantification of expression levels.

\section{[FeFe]-hydrogenase genes of C. beijerinckii AM2 and C. tyrobutyricum AM6}

Fermentative hydrogen production in the genus Clostridium is related with the activity of the [FeFe]-hydrogenases, these enzymes use protons as the final electron acceptors in the cellular energy metabolism. In general the transcription of [FeFe] hydrogenases encoding genes has been previously applied also in meta-trascriptomic approaches to estimate the hydrogen-producing bacterial consortium in selected soils [45].

C. beijerinckii has six genes encoding for different [FeFe]-hydrogenases, 4 monomeric and 2 heterotrimeric and a gene for a [NiFe]-hydrogenase [15]. C. tyrobutyricum has one gene encoding for a monomeric [FeFe]hydrogenase that has been linked to hydrogen production [42] and that until 2016 has been considered as the only [FeFe]-hydrogenase-encoding gene in this strain. Only recently [43] new hypothetical sequences assigned to hydrogenase-encoding genes have been proposed for some specific $C$. tyrobutyricum strains, but these latter sequences were not considered in this work.

Each selected gene encodes a protein belonging to a specific and diverse modular structure type and phylogenetic cluster according to a previously reported classification [15].

The 6 hyd genes of C. beijerinckii are: Cbei_1773 (encoding for a protein with structure type M2c and cluster A5), Cbei_1901 (encoding for a protein with structure type M2a and cluster B2), Cbei_O327 (encoding for a protein with structure type M3a and cluster B3), Cbei_4000 (encoding for a protein with structure type M2b and cluster A2), Cbei_3796 (encoding for a protein subunit with structure type TR (M2) and cluster A3) and Cbei_4110 
(encoding for a protein and catalytic subunit with structure type structure type TR (M3) and cluster A8). The gene hyd of C. tyrobutyricum (Ctyr_hydA) encodes for a protein with structure type M3 and cluster A2. All the gene products are likely to be cytoplasmic, with the exception of those belonging to cluster A3 (structure type TR (M2)). Interestingly enough, the $C$. beijerinckii [FeFe]hydrogenase enzymes have received little attention in the past and even recently the trascriptomics analysis were more focused on other metabolic peculiarities of this strain [46-48], with some indication on genes involved in the hydrogen metabolism only reported in the paper of Patakova et al., 2019 [46].

Although recent works from our group highlighted the peculiarity of at least one of these enzymes [27] and demonstrated the relevance and complexity of their expression in pure cultures [35], the study of their genes expression modulation with quantitative methods has never been performed before. The $C$. tyrobutyricum [FeFe]-hydrogenase protein selected and targeted in this study is known to be involved in $\mathrm{H}_{2}$ production [42], but no studies are reported on the gene expression analysis of this enzyme.

The activity of [FeFe]-hydrogenases can be regulated at metabolic level through regulatory controls at transcriptional level [13].

It is already known that Clostridia present more than one gene encoding for [FeFe]-hydrogenases, which could be subjected to different expression modulation [49]; one aim of this research was the identification of the relationship between the performance of dark fermentation on a real and nutrient-poor green waste, already containing a mixed microbial consortium, and the expression of [ $\mathrm{FeFe}]$-hydrogenase genes, by measuring on the same samples the transcription levels of the selected genes and the hydrogen produced.

A previous analysis on the relationship between hydrogen production and [FeFe]-hydrogenases gene expression in C. beijerinckii was performed only in pure cultures and based on semi-quantitative estimate of transcripts [35].

RT-qPCR is a powerful and widely used techniques for detecting and quantifying specific gene expression in vitro. This technique has already been used for quantification of [FeFe]-hydrogenases and has proven to be an accurate assay for quantification of hydrogenase expression levels either in single or mixed bacterial cultures. Nonetheless, the previous studies of hydrogenases genes expression developed in various microorganisms have focused on a single [FeFe]-hydrogenase gene only in bioreactors or multiple [FeFe]-hydrogenase genes expression analysis only in pure cultures $[13,35,49-51]$ or, when in syntrophic co-cultures, only under very controlled and simplified conditions and in rich media [50,52]. Other studies performed on real complex matrices only provided an estimate of the hydrogen-producing consortium composition by metatrascriptomic analysis and were not quantitative [45].

Here, the gene expression modulation in time of the seven genes encoding for [FeFe]-hydrogenase enzymes with different structure types was investigated by RTqPCR in the hydrogen-producing real biomasses waste, hence in presence of the autochthonous strains, both for the non-producers and the hydrogen-producing strains, either with applied bio-augmentation or not.

The recA single copy gene was used to monitor the total bacteria in the medium by quantitative PCR (qPCR). As a population indicator, this gene is a better indicator than the multiple copy $16 \mathrm{~S}$ rRNA-encoding gene (up to 14 copies in C. beijerinckii) that might otherwise compromise the interpretation of the quantitative results, also when the whole genome sequence is unknown, such as in the case of C. tyrobutyricum, in which the estimation of the correct copy number can be problematic [49].

In addition, $r e c A$ gene expression (cDNA) was used as the internal reference gene for RT-qPCR, according to the available literature on Clostridia $[49,53,54]$, to monitor the active bacterial population, since the $r e c A$ expression profile shows the microbial population that is viable and with transcriptional capacity $[49,53,54]$. Also in other bacterial species recA scored as the best in expression stability ranking of the candidate reference genes according to 4 software out of 5 (BestKeeper, NormFinder original softwares and Delta CT and RefFinder analysis) as reported in a recent paper exploring reference genes for gene expression studies using reverse transcription quantitative real-time PCR [55].

Strains specific primers were designed (see Materials and methods) and the specificity was tested experimentally. The maximal recA expression level (Fig. 4A) was detected at $23 \mathrm{~h}$ and then the amount of viable bacteria decreased at $37 \mathrm{~h}$.

After checking the basal expression level of the reference gene $r e c A$, in order to ensure that hydrogen production and transcriptional levels of gene expression were high enough to be detected and properly quantified during the batch dark fermentation process, $C$. beijerinckii AM2 $10^{5} \mathrm{CFU} / \mathrm{mL}$ and C. tyrobutyricum AM6 $10^{6} \mathrm{CFU} / \mathrm{mL}$ were inoculated in the spring green green waste. Methane and hydrogen productions (Fig. 3), metabolically active bacteria C. beijerinckii AM2 and C. tyrobutyricum AM6 as well as 7 hyd genes transcript levels of $C$. beijerinckii AM2 and C. tyrobutyricum AM6 (Fig. 4) were analysed over a period of $288 \mathrm{~h}$. 


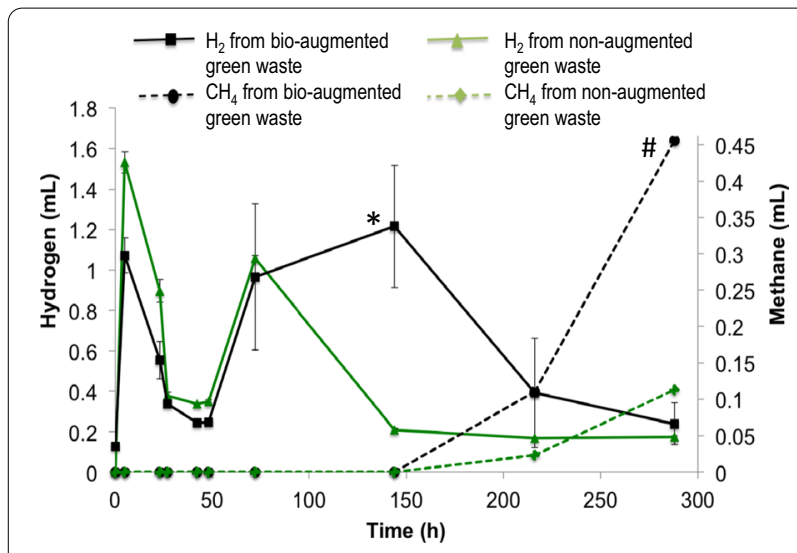

Fig. 3 Cumulative hydrogen (full line, referred to left y-axis) and methane (dashed line; referred to right $y$-axis) production curves during dark fermentation of both hydrogen-producing C. beijerinckii AM2 and C. tyrobutyricum AM6 bio-augmented (black line) and non-augmented (green line) agriculture waste biomass. The values refer to $5 \mathrm{gr}$ of green waste (as detailed in the Materials and Methods section). The VS for this quite heterogeneous material was between 250 and $500 \mathrm{grVS} / \mathrm{kg}$, therefore the cumulative hydrogen production is of $0.6-1.2 \mathrm{ml} \mathrm{H}_{2} / \mathrm{grVS}$, while for methane the cumulative value is of $0.18-0.36 \mathrm{ml} \mathrm{CH}_{4} / \mathrm{grVS}$. Significant differences were determined with a Student's t-test, ${ }^{*} p<0.05, \# p<0.01, \# \# p<0.001$ of bio-augmented versus non-augmented for each timepoint

Gas production in green waste during dark fermentation with and without bio-augmentation with C. beijerinckii AM2 and C. tyrobutyricum AM6

The cumulative curves of gas productions are summarised in Fig. 3, showing the comparison of green waste biomass with $C$. beijerinckii AM2 and C. tyrobutyricum AM6 bio-augmentation as well as green waste biomass alone (reported, respectively, in black and in green).

The hydrogen production curves from both the waste sample with and without bio-augmentation showed a similar trend with a production spike after $5 \mathrm{~h}$, then hydrogen release decreased after $42 \mathrm{~h}$ to increase again after $72 \mathrm{~h}$. A decrease in hydrogen production was observed in the non-bio-augmented sample after $144 \mathrm{~h}$, whereas the waste which underwent bio-augmentation maintained a steady and sustained hydrogen production value, decreasing only after $216 \mathrm{~h}$ due to a rise of $\mathrm{CH}_{4}$ gas. The C. beijerinckii AM2 and C. tyrobutyricum AM6 enrichment did not cause an exponential increase in hydrogen production, but after $150 \mathrm{~h}$ of growth, the bio-augmented batch cultures produced a sixfold higher hydrogen amount, keeping it for a longer period than those from the non-augmented batch.

Methane productions from the bio-augmented sample and the non-augmented waste had a similar trend and methane production is revealed after $216 \mathrm{~h}$; hydrogen and methane productions were mutually exclusive as

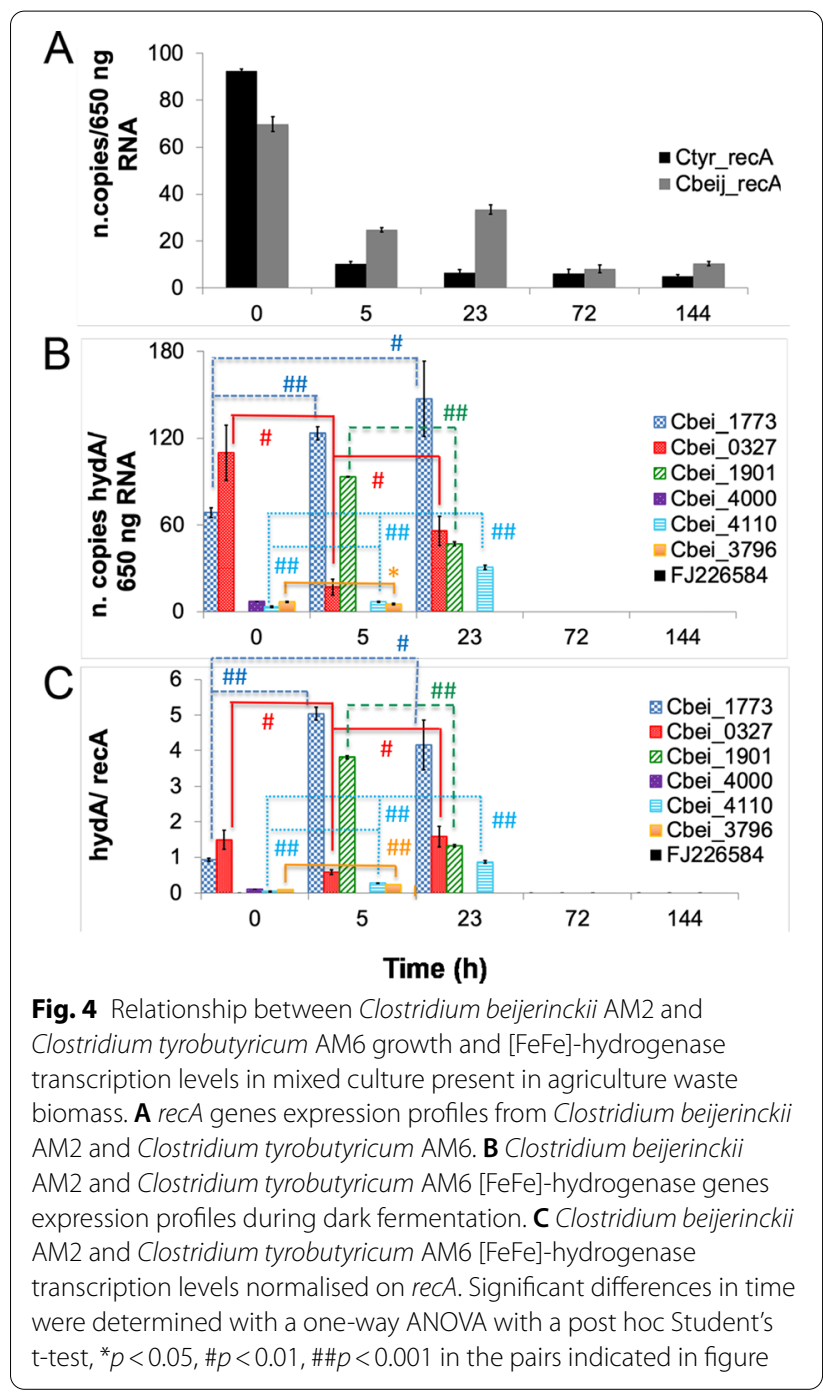

expected [33]. The comparison of the trends in hydrogen and methane production in bio-augmented and nonaugmented samples highlights that the bio-augmented sample is a good indicator of the spontaneous processes occurring in the waste biomass and it suggest that the autochthonous microbial consortium is not significantly inhibited upon addition of an inoculum, but a positive synergy can be implemented between the autochthonous consortium and the inoculum. The advantage of a higher hydrogen concentration, as the one observed in the bioaugmented sample between 72 and $216 \mathrm{~h}$, resulting in a sixfold higher hydrogen amount, points to a possible further optimisation for applicative purposes. A further enhancement of hydrogen production could be achieved by pre-treating the waste in order to inhibit methanogenesis which is obviously here competing with hydrogen accumulation, as reported in Fig. 3. The project supporting the research (funded by EU to enhance bioeconomy 
and circular economy in the Piedmont region) aimed at exploring the potential used of untreated wastes, so no chemical or thermal treatment was applied to hinder methane production.

In the waste biomass bio-augmented with $C$. beijerinckii AM2 and C. tyrobutyricum AM6, the relation between hydrogen production and the modulation of the seven [FeFe]-hydrogenase genes expression was investigated during dark fermentation after set-up of the analysis method by RT-qPCR (Fig. 4).

C. beijerinckii and C. tyrobutyricum recA expressions are indicators of viable and metabolically active populations. Active cells contain more RNA than inactive cells. Predominance of metabolically active $C$. beijerinckii AM2 and C. tyrobutyricum AM6 species was estimated in waste biomass based on RT-qPCR monitoring of $r e c A$ gene during dark fermentation, and C. beijerinckii AM2 prevails over C. tyrobutyricum AM6 although C. tyrobutyricum AM6 was added in larger quantities at the beginning of the process (Fig. 4A).

C. tyrobutyricum AM6 [FeFe]-hydrogenase gene expression was undetectable during the whole analysis, even when a second couple of primers were used to enhance amplification efficiency (Ctyr_hydA see Material and method section). As suggested by the $r e c A$ expression profile (Fig. 4A), this bacterium, isolated from autumnal agriculture waste biomass, was likely to be in a quiescent spore form and not able to sustain an active grow on the green waste biomass under the tested conditions. Although the growth rate were similar in pure cultures for the two tested strains, the competition favoured the growth of $C$. beijerinckii AM2 on the green waste used.

All the C. beijerinckii AM2 [FeFe]-hydrogenase genes are expressed with a variable modulation in the first $23 \mathrm{~h}$ of the fermentative process, while after $72 \mathrm{~h}$ no [FeFe]-hydrogenase transcriptional activity was detected (Fig. 4B and C).

C. beijerinckii AM2 [FeFe]-hydrogenase transcription levels were detected from the beginning of the process. High levels of expression for [FeFe]-hydrogenase genes were observed before optimal hydrogen productions according to the literature [56].

At time 0 (inoculum addition) Cbei_1773 and Cbei_0327 genes were expressed, respectively, 1- and 1.5 -fold more than the genes encoding for the monomeric Cbei_4000, the membrane-bound Cbei_3796 and the catalytic subunit alpha Cbei_4110 of the heterotrimeric [FeFe]-hydrogenases; Cbei_1901 transcription level was not detected at this time point, on the contrary Cbei_4000 transcription was detected only at that time.

After $5 \mathrm{~h}$, when the first peak of hydrogen was observed (Fig. 3), Cbei_1773 and Cbei_1901 genes were expressed, respectively, 5- and 4-fold more than the genes encoding for a monomeric Cbei_0327, a membrane-bound Cbei_3796 and the catalytic subunit alpha of the heterotrimeric Cbei_4110 [FeFe]-hydrogenases (Fig. 4). At least one of the selected, monitored genes that is highly expressed in the early onset of hydrogen production (Cbei_1773) encodes for an unusual [FeFe]-hydrogenase resilient to oxygen damage [27], pointing to a specific role of this enzyme as the main hydrogen-producing catalyst, even if expressed at stages of relatively low anaerobiosis level, and therefore enhancing the tolerance of the whole system to traces of oxygen. Another intriguing hypothesis on the regulation of this gene and on the activity of its encoded protein is the inactivation observed in the protein at oxidative potentials, i.e. when the bacterial cell experiences a shortage in $\mathrm{NAD}(\mathrm{P}) \mathrm{H}$ and other reduced compounds and proteins (ferredoxins and flavodoxins) used to supply electrons. In this situation, a high concentration of an active hydrogenase might impair the redox equilibrium: although this is still a speculative hypothesis, a possible effect of the protein-based inactivation mechanism at high-potential could act as a buffering system and allow for a safer high-level expression enabling the cell to promptly reactivate the hydrogen-producing metabolism. A 99\% similarity to the hydrogenase encoded by C. beijerinckii SM10 [27] Cbei_1773 was also observed in transcriptomic analysis [46] in the coding sequence X276_18165 from C. beijerinckii NRRL B-598, but the authors could not unambiguously assign to this gene the role of expressing the hydrogenase that mainly produces hydrogen in the exponential growth phase of the analysed C. beijerinckii NRRL B-598 strain.

After $23 \mathrm{~h}$, as the hydrogen production decreased (Fig. 3), Cbei_1773, Cbei_0327 and Cbei_1901 genes were expressed, respectively, 4-fold, 1.6-fold and 1.3-fold more than the gene encoding for the catalytic subunit alpha Cbei_4110 of the heterotrimeric [FeFe]-hydrogenases (Fig. 4). Other transcription products were not detected.

During the first $23 \mathrm{~h}$ of dark fermentation, transcription levels of the genes encoding for the monomeric Cbei_1773 and the heterotrimeric Cbei_4110 [FeFe]hydrogenases followed the same trend observed for hydrogen production; transcription levels of the gene encoding for monomeric Cbei_O327 showed a reverse trend compared with that of hydrogen. Expression of Cbei_1901 was detected only after 5 and $23 \mathrm{~h}$ when the amount of hydrogen was different from zero in the batch; Cbei_4000 was expressed only at the initial time point, and Cbei_3796 expression was observed at the first two time points. The decrease of transcripts levels of all genes encoding hydrogenases can be explained partially by a stationary phase and a low transcriptional activity as highlighted by the low recA levels. A relatively 
high hydrogen production level has been reported in Clostridia even at low transcripts amounts, given the good stability of the [FeFe] hydrogenases as active enzymes in the cell, which could explain the relatively high hydrogen accumulation between 23 and $144 \mathrm{~h}$ even with low transcripts detected at 72 and $144 \mathrm{~h}$.

In summary genes Cbei_1773, Cbei_4110,Cbei_0327 and Cbei_1901, which undergo larger changes in expression, seem to be related to hydrogen production, although with positive (Cbei_1773 and Cbei_4110) or negative (Cbei_0327) correlations, hence it would be interesting to further investigate their metabolic roles. In particular, the positive correlation of hydrogen production with Cbei_1773 is relevant given the attested good productivity and the oxygen-tolerance unique feature of the hydrogenase encoded by this gene [27]. Genes Cbei_4000 and Cbei_3796 are possibly less related to hydrogen production and might be silent during dark fermentation. A null expression of Cbei_4000 and negligible levels of Cbei_3796 during hydrogen production were also observed in previous semi-quantitative experiments performed by our group in pure cultures of $C$. beijerinckii SM10 [35], although here a statistically significant change in expression (even if at a low absolute level) can be highlighted (Fig. 4). The range of different structures of the proteins encoded by the analysed genes, in terms of electron transfer domains and possible redox partners supplying or accepting electrons, covers almost completely the whole panel of classified [FeFe]-hydrogenase modular structure arrangements. The results obtained suggest that a specific physiological and functional relevance is linked to each [FeFe]-hydrogenase-encoding gene and that a differential expression in time and fine-tuning of the reciprocal amount and activity of the hydrogenases plays a key role in the entire balance of the redox equilibrium and the hydrogen metabolism in Clostridia. This could justify the redundancy and suggest an increasing evolutionary success for the strains which can rely on a broader range of different $[\mathrm{FeFe}]$ hydrogenases (here $C$. beijerinckii versus $C$. tyrobutyricum). The knowledge of the interplay of different hydrogenase-encoding genes is gaining importance in the study of hydrogen-producing bacteria [57], not only in Clostridia.

A summarising overview of the obtained results as for involved genes and their changes in expression level is reported in Table 1 compared to other similar studies on hydrogen-producing bacteria. Although the very different growth conditions and test strategies, the emerging landscape is that these studies are crucial to optimise the system in bioreactors and to exploit the cell and enzyme catalysts for applicative purposes. In this respect, the results of this work as for the bio-augmentation with C. beijerinckii, are being implemented by the project participating company AgriNewTech Srl to promote reuse of low-value compost and intermediate products (partially composted but unsuitable for completing the process) which cannot be sold on market. The outcomes also suggested economically valuable alternative exploitation of green wastes that can reduce the GHG emission, including a first dark fermentation/anaerobic digestion preliminary process and an optimised (implying low emission) composting process limited to the final digestate.

\section{Conclusions}

RT-qPCR covering the complete set of known [FeFe]hydrogenase gene types $[15,58]$ was performed for the first time in a real and nutrient-poor green waste, usually employed for composting processes but re-addressable for exploitation on other markets [59] and demonstrated to be suitable as dark fermentation substrate. This latter is an advantage over composting due to complete recovery of organic compounds energy as clean fuel (bio-hydrogen or even further to $\mathrm{CO}_{2}$ neutral methane production) and to the demonstrated reduced emission of GHG gas $\left(\mathrm{CH}_{4}\right.$, $\mathrm{N}_{2} \mathrm{O}$ ) otherwise generated by the direct composting process of the green waste [34]. The matrix, containing the autochthonous microbiota was studied with the addition of a supplementary inoculum of endogenous hydrogen producers which confirmed the main role of $C$. beijerinckii in the waste-sustained hydrogen production and a good resilience of the autochthonous consortium to the bio-augmentation strategy applied. The diverse modular structure of the monitored hydrogenases is worth further investigation to evaluate if the architecture of domain arrangement is consistently related to their roles in microbial metabolism and therefore their timing of expression.

The data granted by the different aims of the paper (1: to isolate and characterise robust hydrogen producers, 2 : to provide biochemical characterisation of the interplay of gene expression times/modes in a fermentation on real and complex matrices, 3: to support the enhanced use of green waste in dark fermentation rather than only for composting) are an example of how biochemical studies can support circular bioeconomy.

\section{Materials and methods}

\section{Culture media}

The medium used for bacteria cultures was Clostridial nutrient medium (FLUKA): agar, $0.5 \mathrm{~g} / \mathrm{L}$, L-cysteine hydrochloride, $0.5 \mathrm{~g} / \mathrm{L}, \mathrm{D}(+)$-glucose, $5.0 \mathrm{~g} / \mathrm{L}$, meat extract, $10.0 \mathrm{~g} / \mathrm{L}$, peptone, $5.0 \mathrm{~g} / \mathrm{L}$, sodium acetate, $3.0 \mathrm{~g} / \mathrm{L}$, sodium chloride, $5.0 \mathrm{~g} / \mathrm{L}$, starch, $1.0 \mathrm{~g} / \mathrm{L}$, yeast extract, $3.0 \mathrm{~g} / \mathrm{L}$, final $\mathrm{pH} 6.8 \pm 0.2\left(25^{\circ} \mathrm{C}\right)$. 


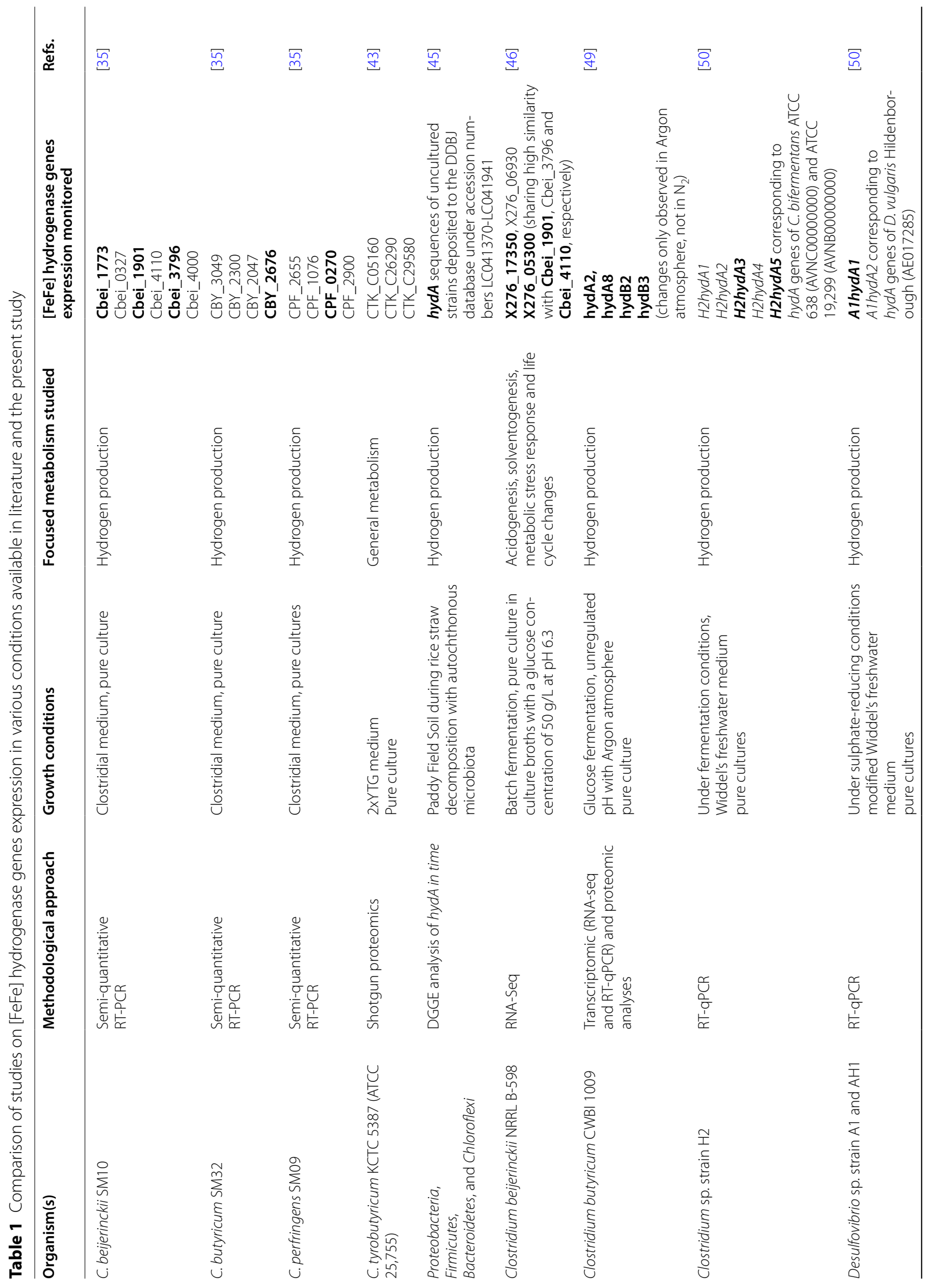




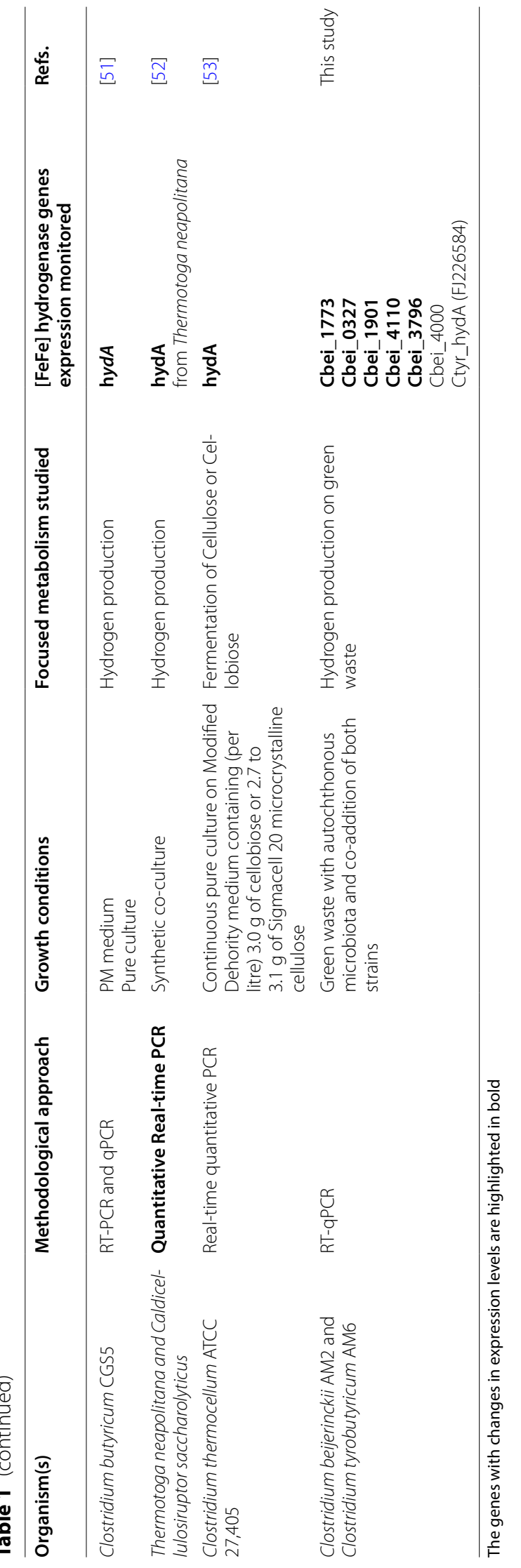


Or else, minimal medium: $100 \mathrm{mM}$ potassium phosphate, $17 \mathrm{~g} / \mathrm{l}$ tryptone, $3 \mathrm{~g} / \mathrm{l}$ peptone papaic digest of soybean, $10 \mathrm{~g} / \mathrm{L}$ glucose, initial $\mathrm{pH}$ 7.0.

All culture media were sterilised by autoclaving for 20 min at $121^{\circ} \mathrm{C}$.

\section{Isolation of culturable bacteria}

The cultivable microbiota present in the nutrient-poor [33] green waste (here referred as Mix, made by pruning of trees and a part of leaves and grass clippings collected in the province of Torino from private and public gardens) was isolated after 41 days of dark fermentation. The flask was opened and non-selective medium was added, then vital cultivable microbiota was isolated by plating of untreated dilution of Mix on Clostridial nutrient medium agar $1.5 \% \mathrm{w} / \mathrm{v}$ with dilutions from $10^{-1}$ to $10^{-5}$. From each dilution $100 \mu \mathrm{l}$ was spread plated (two replicates) and further incubated under anaerobic conditions at $37{ }^{\circ} \mathrm{C}$ overnight. Anaerobic conditions were obtained by using Anaerogen bags (Oxoid) for the plates and fluxing argon for liquid cultures.

In order to select spore-forming microorganisms the same sample was pre-heated at $85{ }^{\circ} \mathrm{C}$ for 20 min prior to dilution from $10^{-1}$ to $10^{-5}$ before plating. In the untreated sample, $2.1 \times 10^{5} \mathrm{CFU} / \mathrm{mL}$ and in the pre-heated sample $1.6 \times 10^{4} \mathrm{CFU} / \mathrm{mL}$ were counted. Following incubation, single and isolated colonies with different morphologies were randomly selected and pure cultures were obtained by an additional passage on plate. Every 4 days, each strain was replicated in a new plate in anaerobic conditions to maintain it viable.

A total of 31 single colonies, 18 from the untreated and 13 from the pre-heated samples, were selected based on the colony morphology for further identification and characterisation. All the isolates were classified based on cell morphology after Gram staining and growth ability also in the presence of oxygen, thus discriminating oxygen-tolerant from oxygen-sensitive microorganisms.

\section{Morphological characterisation}

Gram staining (Fluka kit) was performed to analyse the morphology of the bacteria, which were transferred from fresh plates and spread over a drop of water onto the surface of a clean glass slide. A tenfold dilution was made to the drop of microorganism, which was then placed on a glass slide using an inoculation loop and dried with a Bunsen flame for a few seconds. The slide was then flooded with the Gram's crystal violet solution (Fluka) for $1 \mathrm{~min}$ at most and then removed with water. Gram's iodine solution (Fluka) was used as mordant, applied for $1 \mathrm{~min}$ and washed away again with water. After that, the glass slide was covered with Gram's decolouriser solution (Fluka) for $20 \mathrm{~s}$ followed by washing and flooding with Gram's safranin solution (Fluka) for $1 \mathrm{~min}$ and then washed once again. Morphological examinations were performed with a Reichert microscope. Glass slides were observed through optic microscope at $1000 \times$ magnification using immersion oil.

\section{Genomic DNA extraction and 16S rRNA-encoding gene amplification}

For identification, each isolated strain consisted of bacteria picked up from fresh plates (incubated under anaerobic conditions at $37{ }^{\circ} \mathrm{C}$ overnight) using a sterile loop and it was suspended into $70 \mu \mathrm{L}$ of sterile Milli-Q water. DNA extraction was performed by 3 cycles of freeze/thawing at $90{ }^{\circ} \mathrm{C} /$ liquid nitrogen and centrifuged for $10 \mathrm{~min}$ at max speed. Supernatant was recovered and diluted with $200 \mu \mathrm{L}$ of sterile water.

The 16S rRNA-encoding gene was amplified from genomic DNA by PCR using the proof-reading polymerase "KOD Hot Start DNA polymerase" (Merck Millipore) following the manufacturer's instructions and the two universal primers [44, 51]: 27F: 5'-AGAGTTTGATYMTGG CTCAG-3, 1492R: 5'-TACGGYTACCTTGTTACG ACT-3'.

PCR fragments were separated on $1.5 \%$ agarose gel (TAE $1 \mathrm{X})$ using PerfectSize DNA molecular weight $1 \mathrm{~kb}$ XL ladder as reference (5Prime). The PCR product was purified using Nucleo spin gel and PCR clean-up kit (MachereyNagel) following the manufacturer's instructions.

\section{Restriction fragment length polymorphism (RFLP) analysis of $16 \mathrm{~S}$ rRNA-encoding genes}

The amplified DNA was then digested using four endonuclease restriction enzymes AluI, HaeIII, HhaI and TaqI (Fermentas) separately, in order to obtain RFLP fingerprinting.

The amplified 16S rRNA-encoding gene products were digested following the manufacturer's instructions. DNA fragments were separated by electrophoresis on $1.5 \% \mathrm{w} / \mathrm{v}$ agarose gel 1X TAE stained with $\mathrm{SYBR}^{\circledR}$ Safe (Invitrogen) for $1 \mathrm{~h}$ at $100 \mathrm{~V}, 400 \mathrm{~mA}$. The reference used was PerfectSize DNA molecular weight 100 bp XL Ladder (5 Prime). Scanned images of the gels containing DNA-RFLP were captured with Quantity One software (Bio-Rad).

\section{Sequencing of $16 \mathrm{~S}$ rRNA-encoding genes and phylogenetic analysis}

After classification, one isolate per group was selected. The 16S rRNA-encoding gene was amplified by PCR as described above, purified with a PCR clean-up kit (Macherey-Nagel) and the concentration was evaluated with NanoVue instrument (GE Healthcare). 
The DNA amplified and purified was diluted to a final concentration of $10 \mu \mathrm{g} / \mathrm{mL}$ in a volume of $15 \mu \mathrm{L}$ and then sequenced. The sequencing was carried out by Eurofins MWG Operon Company. The sequences obtained were searched against NCBI, EMBL and DDJB databases using BLASTN 2.0.5. The GenBank accession number of the 16S rRNA-encoding gene sequences are reported below:

group A: MZ054377, group B: MZ054378, group C: MZ054379, group D: MZ054380, group E: MZ054381, group F: MZ054382, group G: MZ054383, group H: MZ054384, group I: MZ054385, group K: MZ054386.

The identity $\geq 99 \%$ with e-value of 0.0 was found for each species.

Phylogenetic trees were constructed by neighbourjoining methods using Molecular Evolutionary Genetics Analysis (MEGA) version 6.06 [60]. The topology of the tree was evaluated by means of bootstrap analysis based on 1000 replicates.

\section{Quantification of $\mathrm{H}_{2}$ and $\mathrm{CH}_{4}$ production}

Pure cultures were grown in a $20-\mathrm{mL}$ glass vial sealed with a butyl rubber stopper, containing $4 \mathrm{~mL}$ of sterile minimal medium under anaerobic argon atmosphere at $37^{\circ} \mathrm{C}, 250 \mathrm{rpm}$ for 16 or $24 \mathrm{~h}$. The negative control was sterile medium without bacteria inoculation. Experiments with the green waste biomass were performed as described previously [33]. The gas was sampled with a syringe SampleLock Gastight syringe (Hamilton) and analysed by a gas chromatographer (Agilent 7890A) with TCD detector. The device was equipped with purged packed inlet, HP-Molesieve 5A column (length $30 \mathrm{~m}$, $0.530 \mathrm{~mm}$ ID, film $25 \mathrm{mM}$ ). Argon, used as carrying gas, had a flow of $0.879 \mathrm{~mL} / \mathrm{min}$. Efficient and quantitative separation was achieved in $2.8 \mathrm{~min}$ at $60^{\circ} \mathrm{C}$, the gas chromatography method allowed the detection of $\mathrm{H}_{2}, \mathrm{O}_{2}, \mathrm{~N}_{2}$, and $\mathrm{CH}_{4}$, respectively, at 1.4, 1.6, 1.9 and $2.4 \mathrm{~min}$. The gas chromatographer injector temperature was $60^{\circ} \mathrm{C}$ and the detector temperature was $250^{\circ} \mathrm{C} . \mathrm{H}_{2}$ and $\mathrm{CH}_{4}$ quantifications were obtained by calibration curves prepared from standard gases (Rivoira, Italy).

\section{Green waste bio-augmented with hydrogen-producing C. beijerinckii AM2 and C. tyrobutyricum AM6 isolates}

For the pre-cultures preparation, anaerobic sterile medium was inoculated with $C$. beijerinckii AM2 or $C$. tyrobutyricum AM6 and incubated at $37{ }^{\circ} \mathrm{C}, 180 \mathrm{rpm}$ for $16 \mathrm{~h}$. For culture preparation $1 \mathrm{~mL}$ of the pre-culture was inoculated in $40 \mathrm{~mL}$ of anaerobic and sterile medium and incubated at $37{ }^{\circ} \mathrm{C} 180 \mathrm{rpm}$ for $16 \mathrm{~h}$. In order to minimise contamination and thoroughly analyse the sample in its original characteristics, the same spring green waste was divided into sterile glass vials with a volume of $60 \mathrm{ml}$. Each vial containing $5 \mathrm{~g}$ of green waste was sealed with butyl rubber stoppers and flushed with argon for $25 \mathrm{~min}$. The bacteria $C$. beijerinckii $5 \times 10^{5} \mathrm{CFU}(1 \mathrm{~mL})$ and C. tyrobutyricum $5 \times 10^{6} \mathrm{CFU}$ were inoculated in each vial by means of a sterile syringe in a sequential manner. All the samples were incubated at $37^{\circ} \mathrm{C}, 220 \mathrm{rpm}$. Ten time points were selected and the gas samples were taken, respectively, after $0,5,23,23,42,48,72,144,216$ and $288 \mathrm{~h}$ from the initial time of incubation. The control group used was the very same spring green waste just without $C$. beijerinckii and C. tyrobutyricum inoculation and the same volume of sterile medium was added to the non-augmented mixture to check real-time performances and compare hydrogen production over the long run. The data collected correspond to the average of two independent samples (biological replicates) analysed at least in triplicate.

\section{RNA extraction and purification}

Metal beads and all glassware used in the isolation of total RNA from green waste were kept at $180{ }^{\circ} \mathrm{C}$ overnight; plasticware was autoclaved before use, whereas solutions used in RNA extractions were treated with $0.1 \%(\mathrm{v} / \mathrm{v})$ diethylpyrocarbonate (DEPC) and autoclaved to inactivate RNases. Two samples per time point were collected immediately. Each sample $(100 \mathrm{mg})$ was homogenised in liquid nitrogen with metal beads using TissueLyserII, then the RLT extraction buffer was added and the tube was incubated at $56^{\circ} \mathrm{C}$ for $1-3 \mathrm{~min}$. Total RNA was extracted and purified in triplicate from the pooled samples following using the kit "Rneasy Plant Mini Kit" (Qiagen). The total RNA was treated with $\mathrm{LiCl}(3 \mathrm{M})$. The sample was incubated at $4{ }^{\circ} \mathrm{C}$ on ice overnight and then RNA was selectively pelleted after centrifugation at $21,000 \mathrm{~g}$ for $30 \mathrm{~min}$ at $4{ }^{\circ} \mathrm{C}$. The pellet was washed with cold ethanol (70\%), dried and resuspended in DEPC-water. The total RNA was treated with Ambion ${ }^{\circledR}$ TURBO DNA-free DNase (Ambion, Life Technologies), according to the manufacturer's instructions. RNA purity and concentration were assessed using a NanoDrop 1000 spectrophotometer (Thermo Scientific, Wilmington, DE, USA) by determining the spectrophotometric absorbance of the samples at 230, 260 and $280 \mathrm{~nm}$ and ratios of $\mathrm{A}_{260}: \mathrm{A}_{280}$ and $\mathrm{A}_{260}: \mathrm{A}_{230}$ (A260/280 $\geq 2$ and $A 260 / 230 \geq 1.8$ ). The RNA integrity was evaluated from the $23 \mathrm{~S}$ and $16 \mathrm{~S}$ rRNA bands on $1.2 \%$ agarose gel after electrophoresis, staining with SYBR $^{\circledR}$ Safe (Invitrogen). The absence of gDNA contamination was tested by omitting reverse transcriptase 
Table 2 List of primers, amplicon fragment size and features

\begin{tabular}{|c|c|c|c|c|c|c|}
\hline Gene description & Forward $\left(5^{\prime}-3^{\prime}\right)$ & Reverse $\left(5^{\prime}-3^{\prime}\right)$ & Size (bp) & $\mathrm{E} \%$ & R2 & $\operatorname{Tm}\left({ }^{\circ} \mathrm{C}\right)$ \\
\hline Ctyr_recA & GTGGAAGCATTGGTTAGATC & GTCCTACATGAGAATCTCCCA & 111 & 101 & 0.98 & 75.1 \\
\hline Cbei_recA & GTCACAGGCGTTAAGAAAGCT & TGCTCTTCCTCCAGTTGTTG & 129 & 87.5 & 0.99 & 74.5 \\
\hline Cbei_1773 & GAGGTTGGGATGGATTCAGA & CCACCTACACACGCCATTA & 161 & 89.3 & 0.99 & 75.6 \\
\hline Cbei_0327 & AGCCTTATTCGATGCGTTTG & TCAATCCACCACCTACAGCA & 104 & 95.9 & 0.99 & 74.8 \\
\hline Cbei_1901 & TTGTGGTGTATGCGTGGATT & AGTACCAAATTGCCCGCTA & 139 & 88.0 & 0.99 & 74.4 \\
\hline Cbei_4000 & AGGGTGGCATAAATGGAGGTG & ССТСTGCССTTCСТСТCTAACA & 140 & 97.1 & 0.99 & 75.3 \\
\hline Cbei_4110 & TGGTGATTGATGGCAATAGG & TCATCCTCGACCACACACAT & 148 & 95.2 & 0.99 & 73.3 \\
\hline Cbei_3796 & TGTTTGCGTTTCTTGTGGAC & TGGCTCCTTCACACTCTCAA & 127 & 103 & 0.98 & 72.7 \\
\hline Ctyr_hydA' & CCATGCCCAAGAAGAGAAAA & GCATTTGGTTCTGTCAAGCA & 144 & 88.0 & 0.99 & 75.0 \\
\hline Ctyr_hydA" & GAGGCAAATGGCAGAACAAT & TTTTCTCTTCTTGGGCATGG & 161 & 95.2 & 0.99 & 74.7 \\
\hline
\end{tabular}

and testing $\mathrm{PCR}$ reaction using specific primers for recA genes by ONE STEP kit (Sigma).

\section{Primers design, reference gene and standard curves preparation}

The specific recA gene is used as an internal reference gene in reverse RT-qPCR. No $\operatorname{rec} A$ gene of $C$. tyrobutyricum was reported in the NCBI database so, from gDNA of $C$. beijerinckii AM2 and C. tyrobutyricum AM6 recA genes were amplified with degenerate primers for Clostridium sp: RecA-F1: 5'-GATGCNGARCAT GCNYTNGA-3', RecA-R1: 5'-CATTYTCHCKWCCYTG DCCWA-3' $(\mathrm{N}=\mathrm{A}, \mathrm{C}, \mathrm{T}, \mathrm{G} ; \mathrm{R}=\mathrm{A}, \mathrm{G} ; \mathrm{Y}=\mathrm{C}, \mathrm{T} ; \mathrm{H}=\mathrm{A}$, $\mathrm{C}, \mathrm{T} ; \mathrm{K}=\mathrm{C}, \mathrm{T} ; \mathrm{D}=\mathrm{A}, \mathrm{T}, \mathrm{G} ; \mathrm{W}=\mathrm{A}, \mathrm{T}$ ), which generated a fragment of around 634 bp [58].

The obtained sequences (GenBank accession numbers: C. beijerinckii AM2 recA: MZ062441, C. tyrobutyricum AM6 recA: MZ062442) were used to design new RT-qPCR primer pairs for $r e c A$ that were specific for $C$. beijerinckii and $C$. tyrobutyricum. The new recA primer pairs were designed by Primer3 tool to obtain amplification products that were no longer than $200 \mathrm{bp}$, as well as cover regions that were conserved within a species and were as different as possible from the other affiliated species. Specificity and cross-reactivity were tested using BLAST (NCBI).

For each hydrogenase gene between 5 and 10 hydA gene sequences encoding for the same structure type hydrogenase from the NCBI (National Center for Biotechnology Information) database were aligned using ClustalW to form 5'-3' consensus sequences. These were used to develop the specific primer sets by AnnHyb tool. The selected sets were synthesised by Eurofins MWG (Germany). The amplicon fragment sizes ranged from 161 to $111 \mathrm{bp}$ as reported in Table 2 .

The complete sequencing of the selected hydrogenases genes was performed. Reference numbers of hydrogenases sequences containing silence or missense mutations and deposited in GenBank are: C. beijerinckii AM2 1773: MZ062438, C. beijerinckii AM2 1901: MZ062439 and C. tyrobutyricum AM6 hydA: MZ062440.

The amplicon sequences were screened using BLAST to determine cross-reactivity.

The specificity for all primer pairs were experimentally evaluated with a range of target and non-target Clostridium species. The primers targeting the $\operatorname{rec} A$ and hyd genes were specific (100\% identity) also when used in RT-qPCR optimisation. No amplification for negative controls was observed. The high specificity of the designed oligonucleotides and their amplification conditions was demonstrated at the specific melting temperatures reported in Table 2, conditions under which all the genes tested showed positive signals. The expected fragment (Table 2) gave a single band when visualised on a $2 \%$ agarose gel. To determine the detection limits, reaction efficiencies and linear ranges of amplification, the standard curves were generated using genomic DNA as reported in Yun et al. [61], DNA was extracted and purified from pure cultures by Wizard genomic DNA purification kit (Promega). Seven tenfold dilutions were freshly prepared each time from the DNA, ranging from 15 to $15 \times 10^{-5} \mathrm{ng} / \mu \mathrm{l}$. The good linearity is demonstrated by linear correlation coefficient $\left(R^{2}\right)$ value $\geq 0.98$ for six orders of magnitude for all the genes and the slope of the regression curve showed efficient yields ranging between 101 and $87.5 \%$ the values for each primers couple are reported in Table 2 .

\section{cDNA synthesis and real-time qPCR}

The first-strand cDNA was synthesised starting from $0.645 \mu \mathrm{g}$ of total RNA by using a selected iScript Reverse Transcriptase (Invitrogen) following the manufacturer's instructions. The analysis was performed in 96-well plate using SYBR Green method (Power SYBR ${ }^{\circledR}$ 
Green PCR Master Mix, Applied Biosystems). The PCR reaction mix contained $1 \mu \mathrm{L}$ of cDNA, $0.2 \mathrm{mM}$ dNTPs, $0.2 \mu \mathrm{M}$ each primer, $1.5 \mathrm{mM} \mathrm{MgCl}_{2}$ and 0.5 unit Taq polymerase. Cycling conditions consisted of an initial denaturation phase at $95{ }^{\circ} \mathrm{C}$ for $10 \mathrm{~min}$, followed by 40 cycles at $95{ }^{\circ} \mathrm{C}$ for $15 \mathrm{~s}$ and $60{ }^{\circ} \mathrm{C}$ for $1 \mathrm{~min}$. At the end of each RT-qPCR run, a melting analysis was carried out to verify the absence of non-specific amplification with $95{ }^{\circ} \mathrm{C}$ for $15 \mathrm{~s}, 60{ }^{\circ} \mathrm{C}$ for $1 \mathrm{~min}$ and $95^{\circ} \mathrm{C}$ for $15 \mathrm{~s}$ with a transition rate of $0.3^{\circ} \mathrm{C}$ every $10 \mathrm{~s}$. Non-RT controls (using total RNA without reverse transcription to monitor for genomic DNA contamination) and non-template controls (water instead of template) were included in all runs. Gene expression was determined as the mean, and standard errors were calculated over all biological and technical replicates. The standard curve was generated by performing three independent serial dilutions of the DNA standard and by assaying each dilution in duplicate together with negative control reactions. In order to calculate the copy number of each target gene in the samples the standard curve method was used and the hydrogenase gene expression was normalised on the total RNA and later on the reference gene expression.

\section{Acknowledgements}

M.A. acknowledges Fondazione CRT and AgriNewTech srl for supporting Lagrange Project Applied Research Scholarships.

\section{Authors' contributions \\ All authors contributed to this study. FV, MP, SM, MA set the background for the feasibility study and decided the experimental plan. GG and MLG contrib- uted to the conception and design. MA performed most of the experiments together with SM. MA, SM and FV analysed the data. MA and FV prepared the original draft. All authors were involved in critically reviewing all data and in writing the final manuscript. All authors read and approved the final manuscript.}

\section{Funding}

This work was supported by project Compidro (E.U. Structural Funds, Piedmont Region, Poli di Innovazione, POR F.E.S.R.) and by AgriNewTech srl.

\section{Availability of data and materials}

All data generated or analysed during this study are included in this published article.

\section{Declarations}

Ethics approval and consent to participate

Not applicable.

\section{Consent for publication}

Not applicable.

\section{Competing interests}

MP declares he has a financial interest as he is a shareholder in the AgriNewTech company that partially supported this work. The other authors declare that the have no competing interest.

\section{Author details}

'Department of Life Sciences and Systems Biology, University of Torino, Via Accademia Albertina 13, 10123 Torino, Italy. ${ }^{2}$ Centre of Competence for Innovation in Agro-Environmental Field (Agroinnova) and DiSAFA, University of Torino, Largo Paolo Braccini 2, 10095 Grugliasco, TO, Italy. ${ }^{3}$ AgriNewTech Srl, Via Livorno 60, 10140 Torino, Italy. ${ }^{4}$ Present Address: Faculty of Engineering, University of Nottingham, Nottingham, UK. ${ }^{5}$ Present Address: Acea Engineering Laboratories Research Innovation SpA, Roma, Italy.

Received: 6 October 2020 Accepted: 28 August 2021

Published online: 16 September 2021

\section{References}

1. Abreu A, Alves JI, Pereira MA, Karakashev D, Alves MM, Angelidaki I. Engineered heat treated methanogenic granules: a promising biotechnological approach for extreme thermophilic biohydrogen production. Bioresour Technol. 2010;101:9577-86.

2. Zhao $X$, Xing D, Fu N, Liu B, Ren N. Hydrogen production by the newly isolated Clostridium beijerinckii RZF-1 108. Bioresour Technol. 2011;102:8432-6.

3. Jung KW, Kim DH, Kim SH, Shin HS. Bioreactor design for continuous dark fermentative hydrogen production. Bioresour Technol. 2011;102:8612-20.

4. Kim TH, Lee Y, Chang KH, Hwang SJ. Effects of initial lactic acid concentration, HRTs, and OLRs on bio-hydrogen production from lactate-type fermentation. Bioresour Technol. 2012;103:136-41.

5. Barca C, Soric A, Ranava D, Giudici-Orticoni MT, Ferrasse JH. Anaerobic biofilm reactors for dark fermentative hydrogen production from wastewater: a review. Bioresour Technol. 2015;185:386-98.

6. Kumar G, Sivagurunathan P, Park JH, Park JH, Park HD, Yoon JJ, Kim SH. HRT dependent performance and bacterial community population of granular hydrogen-producing mixed cultures fed with galactose. Bioresour Technol. 2016;206:188-94.

7. Kumar G, Shobana S, Nagarajan D, Lee DJ, Lee KS, Lin CY, Chen CY, Chang JS. Biomass based hydrogen production by dark fermentation-recent trends and opportunities for greener processes. Curr Opin Biotechnol. 2018:50:136-45.

8. Wang J, Bibra M, Venkateswaran K, Salem DR, Rathinam NK, Gadhamshetty V, Sani RK. Biohydrogen production from space crew's waste simulants using thermophilic consolidated bioprocessing. Bioresour Technol. 2018:255:349-53.

9. Rabelo CABS, Soares LA, Sakamoto IK, Silva EL, Varesche MBA. Optimization of hydrogen and organic acids productions with autochthonous and allochthonous bacteria from sugarcane bagasse in batch reactors. J Environ Manage. 2018;223:952-63.

10. Yang G, Wang J. Changes in microbial community structure during dark fermentative hydrogen production. Int J Hydrog Energy. 2019:44:25542-50.

11. Xiao Y, Zhang X, Zhu M, Tan W. Effect of the culture media optimization, $\mathrm{pH}$ and temperature on the biohydrogen production and the hydrogenase activities by Klebsiella pneumoniae ECU-15. Bioresour Technol. 2013;137:9-17.

12. Zahedi S, Solera R, Micolucci F, Cavinato C, Bolzonella D. Changes in microbial community during hydrogen and methane production in twostage thermophilic anaerobic co-digestion process from biowaste. Waste Manag. 2016;49:40-6.

13. Tolvanen KES, Korskinen PEP, Ylikoski A, Hemmila O, Puhakka J, Karp MT. Quantitative monitoring of a hydrogen-producing Clostridium butyricum strain from a continuous-flow, mixed culture bioreactor employing realtime PCR. Int J Hydrog Energy. 2008;33:542-9.

14. Vignais PM, Billoud B. Occurrence, classification, and biological function of hydrogenases: an overview. Chem Rev. 2007;107:4206-72.

15. Calusinska M, Happe T, Joris B, Wilmotte A. The surprising diversity of clostridial hydrogenases: a comparative genomic perspective. Microbiology. 2010;156:1575-88.

16. Therien JB, Artz JH, Poudel S, Hamilton TL, Liu Z, Noone SM, Adams MWW, King PW, Bryant DA, Boyd ES, Peters JW. The physiological functions and structural determinants of catalytic bias in the [FeFe]-hydrogenases $\mathrm{Cpl}$ and Cpll of Clostridium pasteurianum strain W5. Front Microbiol. 2017:8:1305

17. Nicolet Y, Piras C, Legrand P, Hatchikian CE, Fontecilla-Camps JC. Desulfovibrio desulfuricans iron hydrogenase: the structure shows unusual coordination to an active site Fe binuclear center. Structure. 1999;1:13-23. 
18. Peters JW, Lanzilotta WN, Lemon BJ, Seefeldt LC. X-ray crystal structure of the Fe-only hydrogenase (Cpl) from Clostridium pasteurianum to 1.8 Angstrom resolution. Science. 1998;282:1853-8.

19. Demuez M, Cournac L, Guerrini O, Soucaille P, Girbal L. Complete activity profile of Clostridium acetobutylicum [FeFe]-hydrogenase and kinetic parameters for endogenous redox partners. FEMS Microbiol Lett. 2007;275:113-21.

20. Happe T, Naber JD. Isolation, characterization and N-terminal amino acid sequence of hydrogenase from the green alga Chlamydomonas reinhardtii. Eur J Biochem. 1993;214:475-81.

21. Caserta G, Adamska-Venkatesh A, Pecqueur L, Atta M, Artero V, Roy S, Reijerse E, Lubitz W, Fontecave M. Chemical assembly of multiple metal cofactors: the heterologously expressed multidomain [FeFe]hydrogenase from Megasphaera elsdenii. Biochim Biophys Acta. 2016;1857:1734-40

22. Chongdar N, Birrell JA, Pawlak K, Sommer C, Reijerse EJ, Rüdiger O, Lubitz W, Ogata H. Unique spectroscopic properties of the H-cluster in a putative sensory [FeFe] hydrogenase. J Am Chem Soc. 2018;140:1057-68.

23. Engelbrecht $V$, Rodríguez-Maciá P, Esselborn J, Sawyer A, Hemschemeier A, Rüdiger O, Lubitz W, Winkler M, Happe T. The structurally unique photosynthetic Chlorella variabilis NC64A hydrogenase does not interact with plant-type ferredoxins. Biochim Biophys Acta. 2017;1858:771-8.

24. Greene BL, Schut GJ, Madams MWW, Dyer BR. Pre-steady-state kinetics of catalytic intermediates of an [FeFe]-hydrogenase. ACS Catal. 2017;7:2145-50

25. Land H, Ceccaldi P, Mészáros LS, Lorenzi M, Redman HJ, Senger M, Stripp ST, Berggren G. Discovery of novel [FeFe]-hydrogenases for biocatalytic H 2-production. Chem Sci. 2019;10:9941-8.

26. Morra S, Valetti F, Sarasso V, Castrignanò S, Sadeghi SJ, Gilardi G. Hydrogen production at high Faradaic efficiency by a bio-electrode based on $\mathrm{TiO}_{2}$ adsorption of a new [FeFe]-hydrogenase from Clostridium perfringens. Bioelectrochemistry. 2015;106:258-162.

27. Morra S, Arizzi M, Valetti F, Gilardi G. Oxygen stability in the new [FeFe]hydrogenase from Clostridium beijerinckii SM10 (CbA5H). Biochemistry. 2016:55:5897-900.

28. Morra S, Mongili B, Maurelli S, Gilardi G, Valetti F. Isolation and characterization of a new [FeFe]-hydrogenase from Clostridium perfringens. Biotechnol Appl Biochem. 2016;63:305-11.

29. Pan CM, Fan YT, Zhao P, Hou HW. Fermentative hydrogen production by the newly isolated Clostridium beijerinckii Fanp3. Int J Hydrogen Energy. 2008;33:5383-91.

30. Polliotto V, Morra S, Livraghi S, Valetti F, Gilardi G, Giamello E. Electron transfer and $\mathrm{H}_{2}$ evolution in hybrid systems based on [FeFe]-hydrogenase anchored on modified $\mathrm{TiO}_{2}$. Int J Hydrog Energy. 2016;41:10547-56.

31. Tomazetto G, Wibberg D, Schlüter A, Oliveira VM. New FeFe-hydrogenase genes identified in a metagenomic fosmid library from a municipal wastewater treatment plant as revealed by high-throughput sequencing. Res Microbiol. 2015;166:9-19.

32. Land H, Sekretareva A, Huang P, Redman HJ, Németh B, Polidori $N$ Mészáros LS, Senger M, Stripp ST, Berggren G. Characterization of a putative sensory [FeFe]-hydrogenase provides new insight into the role of the active site architecture. Chem Sci. 2020. https://doi.org/10.1039/D0SC0 3319G.

33. Arizzi M, Morra S, Pugliese M, Gullino ML, Gilardi G, Valetti F. Biohydrogen and biomethane production sustained by untreated matrices and alternative application of compost waste. Waste Manag. 2016;56:151-7.

34. Zhu-Barker X, Bailey SK, Paw UKT, Burger M, Horwath WR. Greenhouse gas emissions from green waste composting windrow. Waste Manag. 2017:59:70-9.

35. Morra S, Arizzi M, Allegra P, La Licata B, Sangnelli F, Zitella P, Gilardi G, Valetti F. Expression of different types of [FeFe]-hydrogenase genes in bacteria isolated from a population of a biohydrogen pilot-scale plant. Int J Hydrog Energy. 2014;39:9018-27.

36. Tohno M, Kobayashi H, Tajima K, Uegaki R. Strain-dependent effects of inoculation of Lactobacillus plantarum subsp. plantarum on fermentation quality of paddy rice (Oryza sativa L. subsp. japonica) silage. FEMS Microbiol Lett. 2012;337:11-29.

37. Ten LN, Wan-Taek IM, Sang-Hoon B, Jung-Sook L, Hee-Mock O, Sung-Taik L. Bacillus ginsengihumi sp. nov., a novel species isolated from soil of a ginseng field in Pocheon province, South Korea. J Microbiol Biotechnol. 2006;16:1554-60.
38. Valdez-Vazquez I, Morales AL, Escalante AE. History of adaptation determines short-term shifts in performance and community structure of hydrogen-producing microbial communities degrading wheat straw. Microb Biotechnol. 2017;10:1569-80.

39. Jia X, Xi B-D, Li M-X, Yang Y, Wang Y. Metaproteomics analysis of the functional insights into microbial communities of combined hydrogen and methane production by anaerobic fermentation from reed straw. PLoS ONE. 2017;12:e0183158.

40. Gomez-Romero J, Gonzalez-Garcia A, Chairez I, Torres L, García-Peña El. Selective adaptation of an anaerobic microbial community: biohydrogen production by co-digestion of cheese whey and vegetables fruit waste. Int J Hydrog Energy. 2014;39:12541-50.

41. Noparat P, Prasertsan P, O-Thong S. Isolation and characterization of high hydrogen-producing strain Clostridium beijerinckii PS-3 from fermented oil palm sap. Int J Hydrog Energy. 2011;36:14086-92.

42. Jo JH, Jeon GO, Lee SY, Lee DS, Park JM. Molecular characterization and homologous overexpression of [FeFe]-hydrogenase in Clostridium tyrobutyricum JM1. Int J Hydrogen Energy. 2010;35:1065-73.

43. Lee J, Jang YS, Han MJ, Kim JY, Lee SY. Deciphering Clostridium tyrobutyricum metabolism based on the whole-genome sequence and proteome analyses. MBio 2016;7: e00743-16.

44. Wang $X$, Hoefel D, Saint CP, Monis PT, Jin B. The isolation and microbial community analysis of hydrogen producing bacteria from activated sludge. J Appl Microbiol. 2007;103:1415-23.

45. Baba R, Asakawa $\mathrm{S}$, Watanabe T. $\mathrm{H}_{2}$-producing bacterial community during rice straw decomposition in paddy field soil: estimation by an analysis of [FeFe]-hydrogenase gene transcripts. Microbes Environ. 2016;31:226-33.

46. Patakova P, Branska B, Sedlar K, Vasylkivska M, Jureckova K, Kolek J, Koscova P, Provaznik I. Acidogenesis, solventogenesis, metabolic stress response and life cycle changes in Clostridium beijerinckii NRRL B-598 at the transcriptomic level. Sci Rep. 2019;9:1371.

47. Sedlar K, Koscova P, Vasylkivska M, Branska B, Kolek J, Kupkova K, Patakova P, Provaznik I. Transcription profiling of butanol producer Clostridium beijerinckii NRRL B-598 using RNA-Seq. BMC Genomics. 2018;19:415.

48. Vasylkivska M, Jureckova K, Branska B, Sedlar K, Kolek J, Provaznik I, Patakova P. Transcriptional analysis of amino acid, metal ion, vitamin and carbohydrate uptake in butanol-producing Clostridium beijerinckii NRRL B-598. PLOS ONE. 2019;14(11):e0224560.

49. Calusinska M, Hamilton C, Monsieurs P, Mathy G, Leys N, Franck F, Joris $B$, Thonart P, Hiligsmann S, Wilmotte A. Genome-wide transcriptional analysis suggests hydrogenase- and nitrogenase-mediated hydrogen production in Clostridium butyricum CWBI 1009. Biotechnol Biofuels. 2015;22:8-27.

50. Baba R, Morita M, Asakawa S, Watanabe T. Transcription of [FeFe]-hydrogenase genes during $\mathrm{H} 2$ production in Clostridium and Desulfovibrio spp. isolated from a paddy field soil. Microbes Environ. 2017;32:125-32.

51. Wang MY, Tsai YL, Olson BH, Chang JS. Monitoring dark hydrogen fermentation performance of indigenous Clostridium butyricum by hydrogenase gene expression using RT-PCR and qPCR. Int J Hydrog Energy. 2008;33:4730-8.

52. Okonkwo O, Lakaniemi A-M, Santala V, Karp M, Mangayil R. Quantitative real-time PCR monitoring dynamics of Thermotoga neapolitana in synthetic co-culture for biohydrogen production. Int J Hydrog Energy. 2018;43:3133-41.

53. Stevenson DM, Weimer PJ. Expression of 17 genes in Clostridium thermocellum ATCC 27405 during fermentation of cellulose or cellobiose in continuous culture. Appl Environ Microbiol. 2005;71(8):4672-8.

54. Savichtcheva O, Joris B, Wilmotte A, Calusinska M. Novel FISH and quantitative $\mathrm{PCR}$ protocols to monitor artificial consortia composed of different hydrogen-producing Clostridium spp. Int J Hydrog Energy. 2011;36:7530-42.

55. Gomes AÉl, Stuchi LP, Siqueira NMG, Henrique JB, Vicentini R, Ribeiro ML, Darrieux M, Ferraz LFC. Selection and validation of reference genes for gene expression studies in Klebsiella pneumoniae using Reverse Transcription Quantitative real-time PCR. Sci Rep. 2018;8(1):9001.

56. Chang JJ, Chou C, Hsu P, You S, Chen W, Lay J. Flow-FISH analysis and isolation of clostridial strains in anaerobic semi-solid biohydrogen producing system by hydrogenase gene target. Appl Microbiol Biotechnol. 2007;74:1126-34. 
57. Greening C, Biswas A, Carere CR, Jackson CJ, Taylor MC, Stott MB, Cook GM, Morales SE. Genomic and metagenomic surveys of hydrogenase distribution indicate $\mathrm{H} 2$ is a widely utilised energy source for microbial growth and survival. ISME J. 2016;10:761-77.

58. Calusinska M, Joris B, Wilmotte A. Genetic diversity and amplification of different clostridial [FeFe] hydrogenases by group-specific degenerate primers. Lett Appl Microbiol. 2011;53:473-80.

59. De Corato U, De Bari I, Viola E, Pugliese M. Assessing the main opportunities of integrated biorefining from agro-bioenergy co/by-products and agroindustrial residues into high-value added products associated to some emerging markets: a review. Renew Sustain Energy Rev. 2018;88:326-46.
60. Tamura K, Stecher G, Peterson D, Filipski A, Kumar S. MEGA6: molecular evolutionary genetics analysis version 6.0. Mol Biol Evol. 2013;30:2725-9.

61. Yun JJ, Heisler LE, Hwang IIL, Wilkins O, Lau SK, Hyrcza M, Jayabalasingham B, Jin J, McLaurin J, Tsao M, Der SD. Genomic DNA functions as a universal external standard in quantitative real-time PCR. Nucleic Acids Res. 2006;34:85-95.

\section{Publisher's Note}

Springer Nature remains neutral with regard to jurisdictional claims in published maps and institutional affiliations.
Ready to submit your research? Choose BMC and benefit from:

- fast, convenient online submission

- thorough peer review by experienced researchers in your field

- rapid publication on acceptance

- support for research data, including large and complex data types

- gold Open Access which fosters wider collaboration and increased citations

- maximum visibility for your research: over 100M website views per year

At BMC, research is always in progress.

Learn more biomedcentral.com/submissions 